\title{
The Press and Nigerian - Cameroun Bakkasi Dispute: A Content Analysis
}

\section{Obi Chukwudi ${ }^{* 1}$, Nworgu KO'1 and Pate $U^{2}$}

${ }^{1}$ College of General and Communication Studies, Micheal Okpara University of Agriculture, Umudike, Nigeria ${ }^{2}$ Bayero University, Kano, Nigeria

\begin{abstract}
Nigerian-Cameroun Boarder dispute was an off-shoot of the indiscriminate partitioning of African by the Europeans. Before the arrival of white man to Africa, Nigeria and Cameroun historically existed as close Neighbours. Therefore, the dispute over Bakassi Peninsula started when the two countries started laying different claims to the oil rich area. However, Bakassi dispute assumed a confrontation dimension with the incessant attacks on Nigerian citizens living in the areas by the Cameroun Gendarme. The main objective of the paper is to content analyze press reports in Nigeria-Cameroun Bakassi dispute in order to appreciate the nature and extent of such reportage. The research methods used are content analysis and library research. The newspapers selected for the studies are namely; The Vanguard, The Daily Times (defunct) The Guardian; This Day and Daily Champion. We did a constructed months study, as developed by Jones and Carter. At one month interval the years studied are 2000 , $2002,2004,20006$ and 2008). To determine the number of editions per paper for the years, a multi-stage systematic sampling was used to select newspapers which gave us 227 editions per paper for the years. We further reduced the editions to be studied by dividing 227 by the number of years studied (5) and we got 45 editions per year. We stratified the editions into years and months to be studied and got 8 editions per paper per month. Therefore, we selected 8 editions from each bundle of 30 editions per month, using a three day study at one day interval, excluding weekend editions in most cases. The code sheet was used for data collection under the following titles; story type (unit of analysis) directionality, story source, placement and content categorization. Frequency table pie charts with sample percentage were used for data analysis and presentation. The validity of the instrument was achieved using face validity by the researchers' colleagues. While reliability was at $10 \%$ of the newspaper contents as suggested by Lacy \& Riffle. The Bakassi dispute between Nigeria and Cameroun attracted a lot attention, especially after the world court ruling which ceded the oil rich Bakassi Peninsula to Cameroun. Also the Green - tree agreement which actually led to rectification and implementation of the court ruling by handing over of the disputed area to Cameroun during Obasanjo's administration also attracted a lot of commentaries from Nigerians, including the press. In most press stories, Nigerian citizens expressed their opposition to the government poor handing of the relocation of the Bakassi people, who see themselves as historically Nigerians.
\end{abstract}

Keywords: Implementation; People; Newspapers; Communication

\section{Background of the Study}

Nigerian - Cameroun Boarder dispute was an off-shoot of the indiscriminate partitioning of African by the Europeans. Before the arrival of white man to Africa, Nigeria and Cameroun historically existed as close Neighbours. Therefore, the dispute over Bakassi Peninsula started when the two countries started laying different claims to the oil rich area. However, Bakassi dispute assumed a confrontation dimension with the incessant attacks on Nigerian citizens living in the areas by the Cameroun Gendarme. Also, based on the vested interest of some western countries in exploring the oil in the area, the dispute gained international attention and interest, with France and other western countries supporting Cameroun's claims to the land.

Nigeria, which was under military regime of both Generals Babangida and Abacha at different time, may not have mustered enough international support on her claim over the land. The dispute over the land became more confrontational during military regime of the late Gen Sani Abacha, who deployed Nigerian troop to occupy the area usually occupied, by the Cameroonian gendarme. The occupation forced Cameroun to file a suit claiming the land at the international court of justice at The Hague. After many years of legal battle, Cameroun won the claim over the land and Nigeria was asked to immediately hand over the oil-rich Bakassi Peninsula to Cameroun. This was effected during the civilian administration of President Olusegun Obasanjo under the Green- Tree agreement supervised by the world court and other international bodies. Therefore, the Bakassi dispute attracted a lot media attention, especially, after the world court ruling. This is the trust of this paper.

\section{Statement of the Problem}

Did Nigerian Press report on Bakassi Boarder dispute between Nigeria and Cameroun? What was the nature of press reportage on the dispute? To what extent did press reports on the dispute help or mere Nigerian's chances of claiming the disputed areas? These questions are necessary because the press can play a vital in conflict management and resolution; especially through objective reporting. There are instances where press reports may have to form good evidence in resolving disputes over issues, and land territories.

Investigative and interpretative reporting have provided journalist a good strategy and skill to engage through information seeking and giving in the area of conflict. Hence, Nigerian press was expected to contribute to the peaceful resolution of the dispute between Nigeria and Cameroun, especially, as regards Cameroun claim that area was created to her by gowns administration at weak of Nigerian civil war.

*Corresponding author: Obi Chukwudi, College of General and Communication Studies, Micheal Okpara University of Agriculture, Umudike, Nigeria, Tel: +2348030902410; E-mail: chukwudiobi74@gmail.com

Received January 20, 2018; Accepted September 11, 2018; Published September 08, 2018

Citation: Chukwudi O, Nworgu KO, Pate U (2018) The Press and Nigerian - Cameroun Bakkasi Dispute: A Content Analysis. J Mass Communicat Journalism 8: 388. doi: 10.4172/2165-7912.1000388

Copyright: (c 2018 Chukwudi O, et al. This is an open-access article distributed under the terms of the Creative Commons Attribution License, which permits unrestricted use, distribution, and reproduction in any medium, provided the original author and source are credited. 
The extent to which the press reports educated, informed or enlightened the citizens on the issued at stake was the thrust of this paper.

\section{Objectives of the Study}

The main objective of the paper is to content analyze press reports in Nigeria - Cameroun Bakassi dispute to appreciate the nature and extent of such reportage. In addition to that, the paper will achieve the following objective:

1 Ascertaining the story, sources, types and depth on the Nigeria - Cameroun order dispute

2 Identifying the prominence and directionality of the stories on the dispute.

3 Outlining the content categories of the press reports on the dispute

\section{Research questions}

The researcher answered the following questions

RQ1: What are the sources, story, types and depth on Nigeria Cameroun border dispute?

RQ2: What are the directionality and prominence of the Nigerian press reportage on border dispute?

RQ3: What are the content categorizations of reports on Nigeria Cameroun border dispute?

\section{Theoretical Frame Work}

The study is anchored on the consent engineering of concept. This is a term coined by the father of modern Public Relations Edwards L. Bernay. The concept is aimed expanding the freedom of press and speech in order to include government freedom to persuade only by mastering the techniques of communication leadership can exercise fruitfully in the vest complex that is modern democracy, result do not just happen [1].

It is a process of trying to get parties to a conflict to agree on terms or conditions necessary for effective management of the conflict. It is public relations oriented. Nigerian government propagandist used similar technique in their efforts to garner support from Nigerian citizens over Bakassi Peninsula dispute. Successive government found it convenient to use the excuse of protection of lives and property of Nigerian in the peninsula annex and invade the area from time to time. Sometimes, with sight provocation from Cameroonian garmades, Nigerian Army usually invades Bakassi area. Hence, if opponents are allowed to freely communicate their message, stand - off will result in which no one wins Propagandists are convinced of the validity of their cause, so they must stop opponents from blocking their actions.

During the Bakassi peninsular dispute between Nigeria and Cameroun, Nigerian press was expected to apply the concept of engineering of consent in convincing Nigerian citizen that the government actions in laying claim to the land is justifiable despite, the fact that there was a written document, indicating that General Gowon's administration ceded the peninsula to Cameroun. This strategy may have informed some of the press reports supporting Nigeria's claim over Bakassi, and the buying into governments.

Also, the second theory for the study is indexing hypothesis. This hypothesis first appeared in an article by Lance its main argument is that news is indexed implicitly to the range and dynamics of government official position. Hence, most issues published in the media are indexed because of or by government officials.

Hence, such news reports may not reflect the public views on such issues. Therefore mass media news professionals from the boardroom to the beat tend to index the views or voices in both news, and editorials from the range of opinions expressed by government official circles. "Most times government seems to have upper hand in this relationship with the press" [2]. In this regard, the press is expected to tow the official line without independent opinion.

Indexing can be used to explain the attitudes of a cross line section Nigerian media over the Bakassi dispute. Hence, while a good number of foreign experts and commentators on public policy issues advocated for dialogue, the media report reflected the government line of arguments that Bakassi peninsula belongs to Nigeria, and that made Cameroun to go to International Court of Justice for a legal solution. At the end, the case went to Cameroun's favour and Nigeria lost the oil-rich peninsula

\section{Literature Review}

\section{Nigeria -Cameroun border: A historical background.}

The dispute between Nigeria and Cameroun was over the Bakassi Peninsula. According to Asobie [3] "The dispute over the Bakassi peninsula is the product of a number contradiction. He noted that the dispute is clash between tradition and modernity. This is because the history of ancient kingdom of Calabar is haunting Nigeria. Before colonialism Bakassi was part of the ancient kingdom was part of the ancient kingdom of Calabar. Hence, Calabar became a part of Nigerian territory. Before now, the people of Bakassi Peninsular owed allegiance to the Obong of Calabar who was the prominent ruler of Calabar kingdom $[3,4]$. Therefore, it was the Obong of Calabar that placed the peninsula and adjoining communities under British protectorate via a treaty of September 10, 1884, with the chiefs of Efiat and Idombi as co-signatories [5].

Later, largely due to political errors and indifference of Nigerian leaders, the republic of Cameroun obtained the Bakassi Peninsula nations in 1959 and 1961. Also through the same process Nigeria obtained some territories which were formerly in Cameroun. But as a result of plebiscite conducted on June 7, 1961, Southern Cameroun became part of the Republic of Cameroun on October 11961 [6].

\section{Nigerian - Cameroun Border Dispute}

Nigerian- Cameroun border dispute started after the scramble and subsequent portioning of Africa and indeed Nigeria. For instance, by the Anglo-German Agreement and protocol of 1913 confirmed by the exchange of letter between the British and German "Cameroun". Hence, Bakassi became a Cameroun territory. However, the United Nation participated in the handing over of Bakassi to Cameroun. After the occupation of Cameroun by allied forces and subsequent renouncing of ownership of the territory under the treaty of Versailles, the area was split into two and placed under the League of Nations mandate. The territory was shared between Britain and France. To this effect, Britain divided its mandate into the northern Cameroun which was administered as part of Northern Nigeria and Southern Cameroun administered under Southern Nigeria.

The quest to retain the southern Cameroun was mentioned by the fact that the Northern was to gain independence in 1960. Hence, Nigeria nursed the interest to administer, Cameroun as part of Nigerian 
territory. However, some people in northern Cameroun wished to reunite the two territories (Northern and Southern Cameroun) as part of republic of Cameroun [7]. The matter was reported to United Nations and International Court of Justice for resolution since opinion was sharply divided on the matter.

Unfortunately, the struggle for Bakassi by both Nigeria and Cameroun is not over the people in the territory, but primarily oil discovered in the place. Nevertheless, the dispute over bakassi territory by Nigeria and Cameroun represents the distortion inherent in Europe's partitioning and colonization of Africa. The Bakassi area was Nigerian territory subsequently partitioned first between France and Britain. This artificial boarder adjustment without recourse to cultural and social affiliations led to wars in Africa including the Nigeria Cameroun "Bakassi dispute. Apart from religious was between Islam and Christianity; boundary disputes have caused more wars among African Neighbours than any other factor. The maps used to carve up African continent were mostly inaccurate: large areas were described as terra incognita. When marking out the boundaries of their new territories, European negotiators frequently resorted to drawing straight line on the ground [8]. Unfortunately Bakassi border dispute between Nigerian and Cameroun are one these Europeans' boundary dissertations, demarcations and partitioning that have found expression in constant skirmishes and drumming of war between the two neighboring countries.

\section{Press and Nigeria's foreign policy over Bakassi Peninsula}

A lot of factors can influence the foreign policy of a nation. For instance, Putnam sees the foreign policy decision making as highly influenced two-level game of diplomacy and domestic policy. Foreign policy is influenced by decision environment and psychological factors. The role of the press in foreign policy has been acknowledged. In Nigeria, this role is reemphased, in the following studies. However, the performance of the press in foreign policy is measured against its adherence to the nation's foreign policy thrust predicted on national interest. Therefore, Nigeria foreign policy is based on true African traditional brotherhood, a PAX NIGERIANA $[9,10]$. This policy was to be the liberation of many African nations from colonialism. However, does such policy thrust exclude the pursuit of legitimate national economic interest? And what should be the role the press in a time of dispute between Nigeria and a sister African country as in the Bakassi dispute? Diplomacy is about actions aimed at relating with other nations based on national interest. Hence, Nigeria's citizen diplomacy pre suppose that the interest of Nigerian citizens should be the preoccupation of both the government and interested parties in Nigeria's foreign policy, including the press. What this implies is that the press was expected to support Nigeria's policy over Bakassi, which before the ICJ ruling, maintained that disputed area was Nigeria's territories.

\section{Research Methodology}

The research methods used are content analysis and library research. The newspapers selected for the study are namely; The Vanguard, The Daily Times (defunct) The Guardian; This Day and Daily Champion. We did a constructed months study, at one month interval the years studied are 2000, 2002, 2004, 20006 and 2008).

To determine the number of editions per paper for the years, a multistage systematic sampling was used to select newspapers which gave us 227 editions per page for years. We further reduced the editions to be study by dividing 227 by the number of years studied (5) and we got 45 editions per year. We stratified the editions into years and months to be studied and got 8 editions per paper per month. Therefore, we selected 8 editions from each bundle of 30 editions per month, using a three day study at one day interval, excluding weekend editions in most cases. The code sheet was used for data collection under the following titles; story type (unit of analysis) directionality, story source, placement and content categorization. Frequency table, pie charts with sample percentage were for data analysis and presentation. The validity of the instrument was achieved using face validity by the researchers' colleagues. While reliability was at $10 \%$ of the newspaper contents as suggested.

\section{Data Presentation}

The Nigerian Cameroun border dispute attracted a total of 148 items. From the five papers reviewed (Figure 1). The Table 1 represents sources of information gathered by the papers. A breakdown of the data shows that the Guardian newspaper had 11.5\% from government source(s), had 7.7\% from corporate bodies, $12.5 \%$ from individual sources, $33.9 \%$ from reporters and $34.8 \%$ from envoys. This Day newspaper had $11.5 \%$ from government sources, $12.5 \%$ from individuals, $6.5 \%$ from reporters' beats, and $8.7 \%$ from envoys. The Daily Champion newspaper had $50 \%$ from government sources, $3.3 \%$ from corporate bodies, $45.8 \%$ from individuals, and $30.6 \%$ from reporters and $30.5 \%$ from envoys. The Vanguard newspaper had 3.8\% from government sources, $16.1 \%$ from reporters, and 3 items $13.0 \%$ from envoys. Daily Times had $23.1 \%$ from government sources, $29.2 \%$ from individuals, $12.9 \%$ from reporters and $13.0 \%$ from envoys (Figure 2).

From Table 2 on the volume of story on Nigeria - Cameroon border dispute, the Guardian had a total of 989.9 inches $24.2 \%$, This Day had a total $10.0 \%$. Daily Champion had 3.0\%, The Vanguard has $6.3 \%$, while Daily Times had $16.7 \%$.

The summary of the result shows that experts view attracted $25.7 \%$ with Daily Champion recording $41.4 \%$. The second highest category is the World Court Judgment on the issues, which recorded $20 \%$, the least $6.8 \%$, was recorded by the history of the disputed land (Figure 3 ).

Table 3 the unit of analysis on the Nigeria - Cameroun border dispute. A breakdown of the figures show that, the Guardian had 16.7\% editorials, $26.3 \%$ news stories, $20 \%$ features, cartoon $20 \%$ and $18.8 \%$ photographs. This Day had $10.5 \%$ news stories, $13.3 \%$ features and $12.5 \%$ photographs. The Daily Champion had $66.7 \%$ editorials $36.8 \%$ news stories, $46.7 \%$ features. The Vanguard had $13 \%$ news stories and $6.3 \%$ photographs. Daily Times had $16.7 \%$ editorial, $13.2 \%$ news stories, $20 \%$ features, $4 \%$ cartoons and $618.8 \%$ photographs.

Table 4 the directionality and prominence of press reports on Nigeria - Bakassi disputes. A breakdown of the result shows that The Guardian has $23.5 \%$ favourable stories $25 \%$ as unfavourable stories and $20.8 \%$ as neutral stories. This Day newspaper had $11.8 \%$ as favourable stories, $12.5 \%$ as unfavourable stories, and $8.3 \%$ as neutral (Figures 4 and 5).

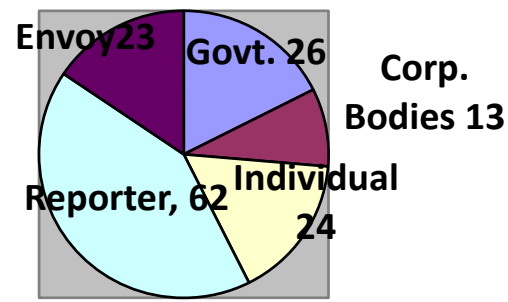

$\square$ Government $\square$ Corp. Bodies $\square$ Individuals $\square$ Reporter Envoy

Figure 1: The Sources of Information Nigerian - Cameroun Border Dispute From 
Citation: Chukwudi O, Nworgu KO, Pate U (2018) The Press and Nigerian - Cameroun Bakkasi Dispute: A Content Analysis. J Mass Communicat Journalism 8: 388. doi: 10.4172/2165-7912.1000388

Page 4 of 7

\begin{tabular}{|c|c|c|c|c|c|c|}
\hline Categories & Government & Corporate Bodies & Individuals & Reporters & Envoys & Total \\
\hline Guardian & $3(11.5 \%)$ & $1(7.7 \%)$ & $3(12.5 \%)$ & $21(33.9 \%)$ & $8(34.8 \%)$ & $36(24.3 \%)$ \\
\hline This Day & $3(11.5 \%)$ & & $3(12.5 \%)$ & $4(6.5 \%)$ & $2(8.7 \%)$ & $12(8.1 \%)$ \\
\hline Champion & $13(50 \%)$ & $12(93.3 \%)$ & $11(5.8 \%)$ & $19(30.6 \%)$ & $7(30.4 \%)$ & $62(41.9 \%)$ \\
\hline Vanguard & $1(3.8 \%)$ & & & $10(16.1 \%)$ & $3(13.0 \%)$ & $14(9.5 \%)$ \\
\hline Daily Times & $6(23.1 \%)$ & & $7(29.2 \%)$ & $8(12.9 \%)$ & $3(13.0 \%)$ & $24(16.2 \%)$ \\
\hline Total & $26(100 \%)$ & $13(100 \%)$ & $24(100 \%)$ & $62(100 \%)$ & $23(100 \%)$ & $148(100 \%)$ \\
\hline
\end{tabular}

Source: Newspaper stories (1999-2009).

Table 1: Represents sources of information gathered by the papers.

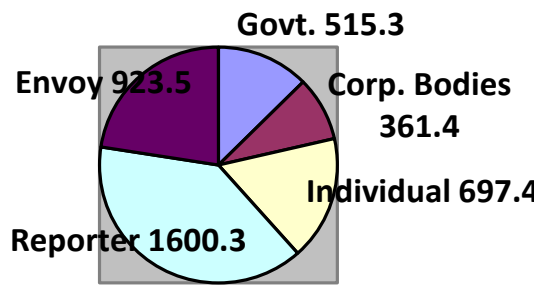

$\square$ Govt
$\square$ Corp. Bodies
$\square$ Individuals
$\square$ Reporter
$\square$ Envoy

Figure 2: Bie Chart2: Volume (Depth) of stories on Bakassi Dispute

\begin{tabular}{|c|c|c|c|c|c|c|}
\hline Categories & Government & Corporate Bodies & Individuals & Reporters & Envoy & Total \\
\hline Guardian & $60.3(11.7 \%)$ & $15(4.2 \%)$ & $68(9.8 \%)$ & $589.1(36.8 \%)$ & $250.5(27.1 \%)$ & $989.9(24.2 \%)$ \\
\hline This Day & $33(6.4 \%)$ & & $85.89(12.3 \%)$ & $197.5(12.3 \%)$ & $94(10.2 \%)$ & $410.4(10.0 \%)$ \\
\hline Champion & $307.2(59.8 \%)$ & $346.4(195.8 \%)$ & $289.5(41.5 \%)$ & $363.8(22.7 \%)$ & $454(49.2 \%)$ & $1760.9(43.0 \%)$ \\
\hline Vanguard & $13.2(2.6 \%)$ & & & $205.3(12.8 \%)$ & $40(4.31 \%)$ & $258.5(6.3 \%)$ \\
\hline Daily Times & $99.6(19.4 \%)$ & & $254(36.4 \%)$ & $244.6(15.3 \%)$ & $84(9.2 \%)$ & $683.2(16.7 \%)$ \\
\hline Total & $513.3(100 \%)$ & $361.4(100 \%)$ & $697.4(100 \%)$ & $1600.3(100 \%)$ & $923.5(100 \%)$ & $4095.9(100 \%)$ \\
\hline
\end{tabular}

Source: Newspaper stories 1999-2009

Table 2: Volume (Depth) of Story on Nigeria-Cameroun Border Dispute (Inches) From 1999-2009

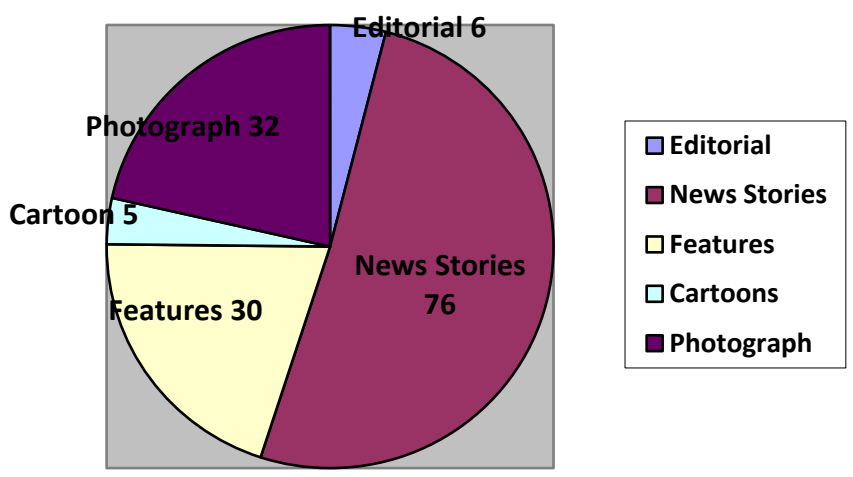

Figure 3: The unit of analysis on the Nigeria - Cameroun border dispute

From Table 5 on content categories on Nigeria - Cameroun border dispute, history of the dispute recorded 6.8\%. A breakdown of the data shows that the Guardian had 5.3\%. This Day had 14.3\% Daily Times had $3.4 \%$, The Vanguard $7.1 \%$ and Daily Times $12.5 \%$.

On the World Court Judgment, The Guardian had 31.6), This Day $14.3 \%$ Daily Champion $17.2 \%$ and Vanguard $28.6 \%$ and The Daily Times $8.3 \%$. The next content category is the Bakassi's people reaction to the dispute and judgment. To this end, a breakdown of the data shows that the Guardian has $18.4 \%$, This Day had $28.6 \%$, Daily Champion had none, Daily Champion had 20.7\%, and The Vanguard had none, while Daily Times had $12.5 \%$. Another category is the experts' view about the dispute and judgment, Hence, The Guardian had $18.4 \%$, This Day had 28.6\%, Daily Champion had 41.4\%, and The Vanguard had none, while Daily Champion had 2.5\%. On the effects of the dispute on the diplomatic relation between the two countries, a breakdown of the data shows that the Guardian had 10.5\% This Day had $14.3 \%$, Daily Champion had $6.9 \%$, The Vanguard had $7,1 \%$ while The Daily Times had 29.2\%.

The summary of the results shows that there were more unfavourable stories published by Nigerian press on Nigerian - Bakassi dispute. This is followed closely by neutral stories. The Daily Champion, on the other hand, had $35.3 \%$ as favourable stories, $31.25 \%$ favourable stories and neutral $33.3 \%$ neutral stories. The Vanguard had $11.8 \%$ as favourable stories, $12.5 \%$ unfavourable stories and $6.7 \%$ as neutral stories. The 
Citation: Chukwudi O, Nworgu KO, Pate U (2018) The Press and Nigerian - Cameroun Bakkasi Dispute: A Content Analysis. J Mass Communicat Journalism 8: 388. doi: 10.4172/2165-7912.1000388

Page 5 of 7

\begin{tabular}{|c|c|c|c|c|c|c|c|}
\hline Paper Titles & Editorials & News Stories & $\begin{array}{c}\text { Letters to } \\
\text { Editor }\end{array}$ & Features & Cartoons & Photographs & Total \\
\hline The Guardian & $1(16.7 \%)$ & $20(26.3 \%)$ & - & $6(20 \%)$ & $1(20 \%)$ & $6(18.8 \%)$ & $34(22.8 \%)$ \\
\hline Thisday & & $8(10.5 \%)$ & - & $4(13.3 \%)$ & & $4(12.5 \%)$ & $16(10.7 \%)$ \\
\hline Daily Champion & $4(66.7 \%)$ & $28(36.8 \%)$ & - & $14(46.7 \%)$ & $2(40 \%)$ & $14(43.8 \%)$ & $62(41.6 \%)$ \\
\hline The Vanguard & & $10(13.2 \%)$ & - & - & - & $2(6.3 \%)$ & $12(8.1 \%)$ \\
\hline The Daily Times & $116.7 \%)$ & $10(13.2 \%)$ & - & $6(20 \%)$ & $2(40 \%)$ & $6(18.8 \%)$ & $25(16.8 \%)$ \\
\hline Total & $6(100 \%)$ & $76(100 \%)$ & & $30(100 \%)$ & $5(100 \%)$ & $32(100 \%)$ & $148(100 \%)$ \\
\hline
\end{tabular}

Source: Newspaper stories (1999-2009)

Table 3: Unit of Analysis (on Nigeria-Cameroun Border Dispute).

\begin{tabular}{|c|c|c|c|c|c|c|}
\hline Content Category & Guardian & This Day & Champion & Vanguard & Daily Times & Total \\
\hline History of the dispute & $2(5.3 \%)$ & $2(14.3 \%)$ & $2(3.4 \%)$ & $1(7.1 \%)$ & $3(12.5 \%)$ & $10(6.8 \%)$ \\
\hline World Court judgment & $12(31.6 \%)$ & $2(14.3 \%)$ & $10(17.2 \%)$ & $4(28.6 \%)$ & $2(8.3 \%)$ & $30(20.3 \%)$ \\
\hline Bakkassi people's reaction & $7(18.4 \%)$ & $4(28.6 \%)$ & $6(10.3 \%)$ & $8(57.1 \%)$ & $3(12.5 \%)$ & $28(18.9 \%)$ \\
\hline Nigerian Citizens reaction & $6(15.8 \%)$ & & $12(20.7 \%)$ & & $6(25 \%)$ & $24(16.2 \%)$ \\
\hline Experts view & $7(18.4 \%)$ & $4(28.6 \%)$ & $24(41.4 \%)$ & & $3(12.5 \%)$ & $38(18.12 .2 \%)$ \\
\hline $\begin{array}{c}\text { Effects of the dispute on diplomatic } \\
\text { relations }\end{array}$ & $4(10.5 \%)$ & $2(14.3 \%)$ & $4(6.9 \%)$ & $1(7.1 \%)$ & $7(29.2 \%)$ & $18(12.2 \%)$ \\
\hline Total & $38(100 \%)$ & $14(100 \%)$ & $58(100 \%)$ & $14(100 \%)$ & $24(100 \%)$ & $148(100 \%)$ \\
\hline
\end{tabular}

Source: Newspaper Content Stories 1999-2009

Table 4: Content Category (2000-2009).

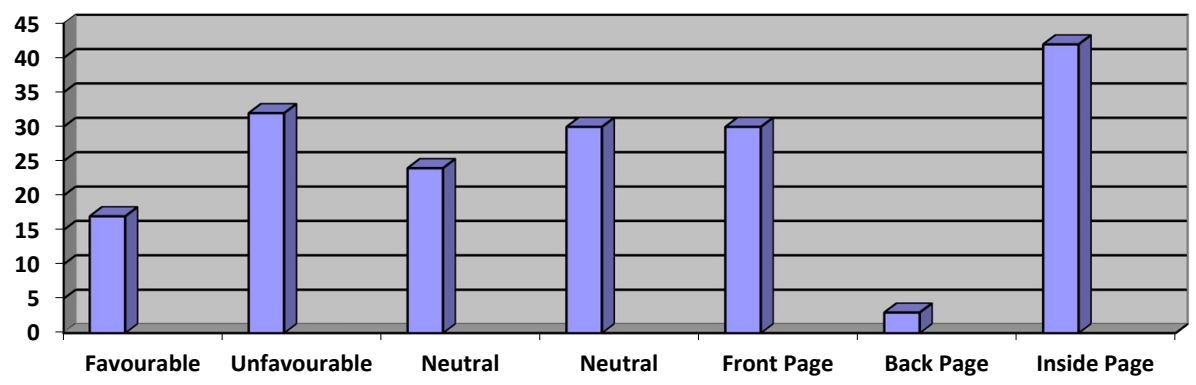

Figure 4: Chart on Directionality and Prominence of Nigeria - Cameroun Dispute

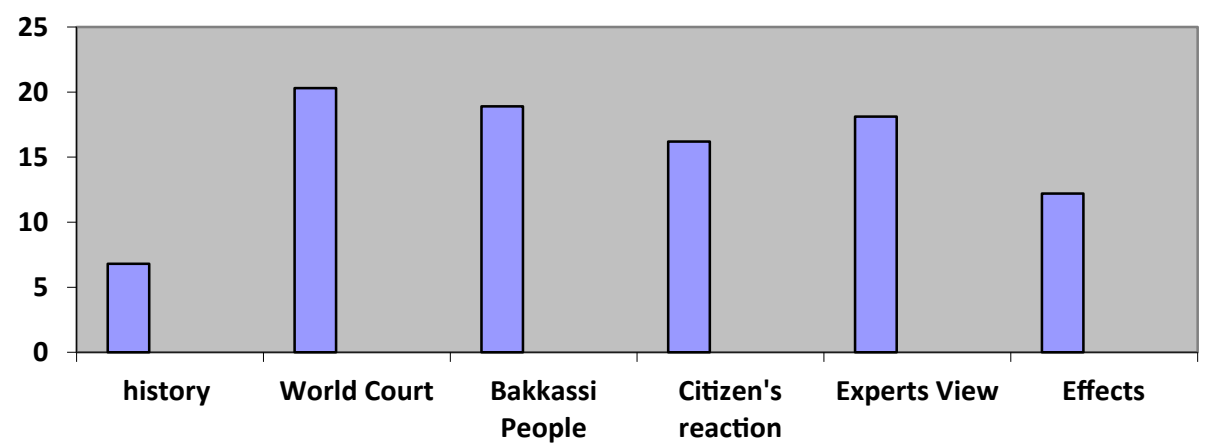

Figure 5: Content categories on Nigeria - Cameroun border dispute

Daily Times had $17.6 \%$ as favourable stories, $18.8 \%$ as unfavourable and $29.2 \%$ as neutral stories.

On prominence placed on the stories about the dispute, placement, in terms front back and inside page were used. The result shows that inside page stories had more reports followed by front page, while back page had the least items. A further breakdown of the data shows that The Guardian had $50 \%$ front page stories, $66.7 \%$ back page stories and
19.0\% inside page stories. Also, we have a total of 30 back page stories; hence, This Day had no back page story, $6.7 \%$ front page stories and $16.7 \%$ inside page stories. Daily Champion had $23.3 \%$ front page stories no back page story, and $26.2 \%$ inside page stories. Also, The Vanguard had $6.7 \%$ front page stories and $16.7 \%$ inside page stories, and no back page story. Daily Times had $13.3 \%$ front page, stories, $33.3 \%$ back page story and $21.4 \%$ inside page stories. 


\begin{tabular}{|c|c|c|c|c|c|c|c|}
\hline Category Title & Favourable Stories & Unfavourable Stories & Neutral & Front Page & Back Page & Inside Page & Total $/ \%$ \\
\hline Guardian & $4(23.5 \%)$ & $8(25 \%)$ & $5(20.8 \%)$ & $15(50 \%)$ & $2(66.7 \%)$ & $8(19.0 \%)$ & $42(28.4 \%)$ \\
\hline This Day & $2(11.8 \%)$ & $4(12.5 \%)$ & $2(8.3 \%)$ & $2(6.7 \%)$ & & $7(16.7 \%)$ & $17(11.5 \%)$ \\
\hline Champion & $6(35.3 \%)$ & $10(31.25 \%)$ & $8(33.3 \%)$ & $7(23.3 \%)$ & & $11(26.2 \%)$ & $42(28.4 \%)$ \\
\hline Vanguard & $2(11.8 \%)$ & $4(12.5 \%)$ & $2(8.3 \%)$ & $2(6.7 \%)$ & & $7(16.7 \%)$ & $17(11.5 \%)$ \\
\hline Daily Times & $3(17.6 \%)$ & $6(18.8 \%)$ & $7(29.2 \%)$ & $4(13.3 \%)$ & $1(33.3 \%)$ & $9(21.4 \%)$ & $30(20.3 \%)$ \\
\hline Total & $17(100 \%)$ & $32(100 \%)$ & $24(100 \%)$ & $30(100 \%)$ & $3(100 \%)$ & $42(100 \%)$ & $148(100 \%)$ \\
\hline
\end{tabular}

Source: Newspaper Content Analysis 1999-2009

Table 5: Directionality and Prominence of Reports on Nigeria-Bakassi Dispute (1999-2009).

\section{Result}

RQ1: What are the sources, Story types and depth on Nigeria Cameroun border dispute?

\section{Nigerian - Cameroun Border Dispute?}

This question was taken care of by the data generated through content analysis of the selected newspapers. The question sought to find out the unit of analysis as used in examining the Nigerian - Cameroun border dispute as contained in the five selected newspapers. The results show that all the papers examined presented the dispute as news stories. However, other units of analysis used by the papers included editorials, letters-to-editor, cartoons, features and photographs. From the data in Photographs had the second highest entries in all the newspapers. Furthermore, the total volume of reports from the five newspapers on the, Nigerian - Cameroun border dispute was 4,095.9 inches. From the results, it is clear that Nigeria - Cameroun border attracted the high length of stories. Therefore, in terms of the length of the stories on Nigeria - Cameroun Border dispute, as measured in column inch, Daily Champion had the highest inches followed by The Vanguard.

RQ2: What are the directionality and prominence of the Nigerian press reportage on the border dispute?

To answer this question, we used data generated from content analysis. Therefore, on directionality and prominence of newspaper publications on Nigeria - Cameroun border dispute, we discovered more unfavourable and neutral stories than favourable ones. Further summary of the prominence of the stories show that those favourable stories on Nigeria Cameroun Border dispute appeared at the inside pages of the newspapers editions reviewed.

The front page got the second highest items, and while back page got the least. Hence, we can say that the dispute was not prominently placed either in front or back pages of the selected newspapers.

RQ3: What are the content Categorization of reports on Nigeria - Cameroun border dispute

This question is answered using data in Table 5. The question tried to look at the angles from which the press reports on the dispute was presented. The content categorization court (ICJ) judgements, the reaction of Bakassi people over the judgement and the dispute itself; Nigerian citizens' reaction to the judgement and experts view on the dispute and judgment and effects of the judgement on the relationship between the two countries. A lot of factors can influence the foreign policy of a nation. For instance, Putnam sees the foreign policy decisionmaking as highly influence by two- level game of diplomacy and domestic policy, it foreign policy is influence by decision environment and psychological factors.

\section{Discussion of Finding}

\section{Nigeria - Cameroun relationship}

Nigeria and Cameroun have historically shared the coastline of the Atlantic Ocean as close Neighbours. The Bakassi peninsula dispute started when the two countries tried to lay claims to the oil - rich area. The Bakassi dispute assumed a confrontational posture during the military regime of the Late Gen. Sani Abacha, who on slight provocation by the Cameroonian Gendarme, deployed Nigerian troops to occupy the area. This led to Cameroun seeking international intervention by going to International Court of justice at Hague Court. After so many years of legal fireworks, Cameroun obtained favourable judgment over the land. Nigeria was asked to hand over the Oil - Rich Bakassi to Cameroun without further delay. The land dispute and consequent world judgment attracted press reports and comments.

The Bakassi dispute between Nigeria and Cameroun attracted a lot attention, especially after the world court ruling which ceded the oil rich Bakassi Peninsula to Cameroun. Also the Green - tree agreement which actually led to rectification and implementation of the court ruling by handing over of the disputed area to Cameroun during Obasanjo's administration also attracted a lot of commentaries from Nigerians, including the press. Some of the press reports on the issue are presented here. In most press stories, Nigeria citizens expressed their opposition to Nigeria's government poor handing of the relocation of the Bakassi people, who see themselves as historically Nigerians [3].

\section{Press reports on Nigeria - Cameroun dispute}

For instance, in a summary headline, entitled; "Bakassi indigenes seek plebiscite", The Guardian wrote plebiscite on Bakassi and a review of the green tree agreement were along requests on foreign affairs minister, by the displaced people of the area. In another favorable story entitled Senator, group take government, UN on Bakassi indigenes' fate, The Guardian wrote that the senator representing Cross River South Bassey Ewa Henshaw, had expressed dissatisfaction over the way the Federal Government was handling Bakassi issues. In yet another favourable story entitled Nigeria, summons Cameroons envoy over Bakassi violence, The Guardian noted that Nigeria's Foreign Affairs Minister Chief Ojo Maduekwe summoned the Cameroonian Charge d'ffairs in Nigeria ostensibly to appraise the reports on violence in the disputed Bakassi Peninsula.

The Daily Champion reported about the resistance of Bakassi people over the handover of the area to Cameroon with such headlines as: Bakassi people threaten Aondoakaa with contempt of court change, The reads, "the embattled indigenes of Bakassi said they would file a contempt of the court charge against the Attorney - General of the Federation if the peninsular is finally handed over to Cameroon. However, the feelings of the people of Bakassi were ignored when the Federal Government finally handed over the place. 
Citation: Chukwudi O, Nworgu KO, Pate U (2018) The Press and Nigerian - Cameroun Bakkasi Dispute: A Content Analysis. J Mass Communicat Journalism 8: 388. doi: 10.4172/2165-7912.1000388

Page 7 of 7

Some of the unfavourable stories on Bakassi issue include: Bakassi: Lawyer Ask FG to Honour Court - Ruling Ita - Giwa head Bakassi Resettlement committee"; 30 Bakassi Returnees Drown; 200 missing; Wrong Judgement on Bakassi: What next after the legal misadventure" and the West's hand in Bakassi Peninsula verdict. In all the above headlines and body stories, the papers expressed the disappointment of the Bakassi people over the World Court judgment and subsequent hand over of the place to Cameroun. The papers in unison condemned the poor handling of the case by Federal Government and the hurry at which they want to hand over the peninsula to Cameroun. For instance, the Daily Champion in story entitled "public opinion and the Bakassi storm" noted that so far the only evidence of any step to sway public opinion to Nigeria's side was the reported comments by the Attorney General and Minister of Justice, Mr. Kanu Agabi, on the World Court verdict on Bakassi. Also, there were few neutral stories which neither supported Nigeria's claim to Bakassi or that of Cameroun. In the neutral stories the papers were calling for peaceful settlement of the dispute without supporting Nigeria or Cameroun. The stories on Nigeria - Cameroun border disputes, represented the patriotism of Nigerian press in protecting national interests. In almost all the reports, the papers unequivocally supported the fact that the Bakassi should belong to Nigeria.

\section{References}

1. Gill S (1997) Global Structural Change and Multilateralism. Globalisation democratization and Multilateralism, pp: 1-17.

2. Golwa JHP (2010) ECOWAS and Management of security in Africa. Reciprocity in Internal relations.

3. Asobie HA (2005) The Political Context and the Contending Principles University of Nigeria Journal of Political Economy 7: 74-104.

4. Abdallah A (2005) Principles of Islamic Conflict Intervention: A Search within Islam and Western Literature. Journal of Law and Religion 15: 151-184.

5. Jinadu LA (2010) Conceptual and Theoretical Issues in the Scramble for Africa. New Scramble for Africa: Lagos NIIA.

6. Fawole WA (2003) Nigeria's External Relations and Foreign Policy unde Miltary Rule 1966 - 1999. Obafemi Awolowo University Press Ltd.

7. Akinnyemi AB (1974) Foreign Policy and Federalism: The Nigerian Experience. Ibadan University Press.

8. Meredith M (2011) The State of Africa: A History of the Continent Since Independence. London: Simon \& Schuster.

9. Eze OC (2009) NIIA and Nigeria's Foreign Economic Policy. Foreign Policy and Nigeria's Economic Development.

10. Almond G (1950) The American people and Foreign Policy. New York: Harcourt Brace. 